\title{
Antagonistic Activity of Pseudomonas Fluorescens Isolates Against Colletotrichum Capsici
}

\author{
${ }^{1}$ Thaveedu S., ${ }^{2}$ Sutha Raja kumar R., ${ }^{3}$ Darwin Christdhas Henry L., Jaiganesh V., Kannan C. \\ Department of Plant Pathology, Faculty of Agriculture, Annamalai University, \\ Annamalai Nagar - 608002, Cuddalore DT, Tamil Nadu. \\ Corresponding author: subirpatho@rediffmail.com
}

\begin{abstract}
The present studies were undertaken to investigate the effect of various isolates of Pseudomonas fluorescens in Tamil Nadu against chilli anthracnose. A total of Six isolates of P. fluorescens were isolated from rhizosphere soil of Major chilli growing areas in various part of Tamil Nadu. All the collected isolates of P. fluorescens were identified and purified using streak method. All the isolated showed results in gram staining (negative), gelatin liquefaction (positive), catalase test (positive), oxidase test (positive), starch hydrolysis (negative) and fluorescent pigmentation (positive) IAA production (positive). Among the various isolates, $\mathrm{Pf}_{1}$ produced more quantity of IAA and siderophores production. Also, $\mathrm{Pf}_{1}$ produced maximum reduction of mycelial growth $\mathrm{C}$. capsici under dual culture and poisoned food techniques.
\end{abstract}

Keywords- Bio control agent, Colletotrichum capsici, Anthracnose, Pseudomonas

\section{INTRODUCTION}

Chilli (Capsicum annum L.) is one of the most important constituent of the cuisines of tropical and subtropical countries and the fourth major crop cultivated globally. Numerous varieties of chilli are grown for vegetables (green fruit), spices (ripe and dried form), condiments, sauces, and pickles occupying an indispensable position in Indian diet. Chilli crop is affected by several fungal, bacterial and viral diseases, of which chilli anthracnose causes considerable damage, inflicting severe quantitative and qualitative losses (Anand et al., 2010; Masoodi et al., 2012). The disease is caused by fungus Colletotrichum capsici that infect both unripe and ripe chilli fruits (Kraikruan et al., 2008). The disease is both seed borne and air borne and affects seed germination and vigour to a great extent (Hemmannuvar et al., 2001).

Several fungicides have been reported to be effective for management of fruit rot of chilli (Shovan et al., 2008). However, indiscriminate use of chemicals led to the development of fungicidal resistance by the pathogen, environmental pollution, health hazards and high cost (Bajpai and Kang, 2010). Hence, a search for alternative methods of plant disease management is on increase. Recently, the role of plant growth promoting rhizobacteria (PGPR) viz., Pseudomonas fluorescens and Bacillus subtilis in biocontrol approaches for managing the pathogen in crop plants are well reported (Allu et al., 2014; Sundaramoorthy and Balabaskar, 2012). Several Pseudomonas strains have been shown to activate ISR in plants against many fungal, bacterial and viral diseases (Chen et al., 2000). Recent investigations on mechanisms of biological control by plant growth promoting fluorescent pseudomonads revealed that several strains protect the plants from pathogen attack by strengthening the epidermal and cortical cell walls with deposition of newly formed barriers beyond infection sites including callose, lignin and phenolics (M'Piga et al., 1997) and production of secondary metabolites such as siderophore, antibiotics, volatile compounds, HCN, enzymes and phytohormones (Nagarajkumar et al., 2004). Hence, exploring the possibilities of identifying an effective native PGPR isolate is essential for the effective management of the disease. Therefore, the present studies were undertaken to investigate the effect of various isolates of Pseudomonas fluorescens against chilli anthracnose.

\section{MATERIALS AND METHODS}

2.1 Isolation and Morphological characterization of Pseudomonas fluorescens

Rhizoplane - colonizing $P$. fluorescens was isolated from fresh roots of chilli grown in six reigns of Tamil nadu. The soil particles loosely adhering to the roots were tested out and used for the isolation of $P$. fluorescens. A soil suspension was prepared from each rhizophere sample by shaking one $\mathrm{g}$ of soil sample in $10 \mathrm{ml}$ of sterile dist. water and serial dilutions were made. One $\mathrm{ml}$ of soil suspension from aliquot dilutions $\left(10^{-5}\right.$ to $10^{-8}$ ) was aseptically added to sterile Petri dishes containing twenty $\mathrm{ml}$ of sterile King's medium and incubated at $28 \pm 2{ }^{\circ} \mathrm{C}$ for $48 \mathrm{~h}$. after incubation, well separated individual colonies with yellow green and blue white pigments were marked and detected by viewing under UV light. The individual colonies were picked up with sterile loop and transferred to fresh King's B slants and the pure cultures so obtained were stored in refrigerator at $4^{\circ} \mathrm{C}$ for further use.

Pure cultures of the selected isolates were streaked on King'B agar Petri dishes separately for colony development. The individual colonies were examined for shape and pigmentation of colonies.

Table 1. Isolation of various isolates of $\boldsymbol{P}$. fluorescens from different locality

\begin{tabular}{|c|l|c|}
\hline Antagonists & \multicolumn{1}{|c|}{ Locality } & Source \\
\hline $\mathbf{P f}_{\mathbf{1}}$ & Aduthurai & $\begin{array}{c}\text { Rhizosphere } \\
\text { Soil }\end{array}$ \\
\hline $\mathbf{P f}_{\mathbf{2}}$ & Cuddalore & Soil \\
\hline $\mathbf{P f}_{\mathbf{3}}$ & Kovilpatti & Soil \\
\hline $\mathbf{P f}_{\mathbf{4}}$ & Sivapuri & Soil \\
\hline $\mathbf{P f}_{\mathbf{5}}$ & Vallampadugai & Soil \\
\hline $\mathbf{P f}_{\mathbf{6}}$ & Vadalore & Soil \\
\hline
\end{tabular}




\section{E-ISSN: 2321-9637 \\ Available online at www.ijrat.org}

\subsection{Biochemical characterization}

For the identification of $P$. fluorescens, certain biochemical test was conducted according to Bergey's Manual for Determinative Bacteriology (Breed et al., 1989).

\section{Gram staining}

A loopful of bacterial culture was transferred on a clean slide and a smear was made which was air dried and heat fixed. The smear was flooded for one min. with ammonium oxylate crystal violet. Excess stain was poured off and the slide was washed in a gentle stream of water. Lugol's iodine solution was applied and allowed to remain for one min. Decolorized with 95 per cent ethyl alcohol. The smear was washed in gentle stream of water and counter stained with safranin for 30 seconds. The Gram negative cells appeared red in color and Gram positive cells appeared violet in color (Cyrabree and Hindshhill, 1975).

\section{Starch hydrolysis}

Filter paper was dipped in a day old culture suspension and was placed on Petri dishes containing starch agar medium and incubated for two days. The plates were than flooded with one per cent iodine solution. A colorless halo around the growth and blue color in rest of the plates showed utilization of starch by the microorganism (Stolpe and Godkeri, 1981).

\section{Gelatin liquefaction}

Filter paper discs were dipped in a day old culture suspension and were placed on Petri dishes containing gelatin nutrient agar medium. The Petri dishes were incubated at $30^{\circ} \mathrm{C}$ for two days and then flooded with 12.5 per cent $\mathrm{HgCl}_{2}$ solution. The development of yellow halo around the growth indicated utilization of gelatin (Stolpe and Godkeri, 1981).

\section{Fluorescent pigmentation}

The test tubes containing sterile King's B medium, inoculated with the isolates of Pseudomonas sp. incubated for five days and observed. Yellowish green fluorescent pigment observed under UV light $(365 \mathrm{~nm})$ indicated positive results (King et al., 1954).

\section{Estimation of IAA}

Indole acetic acid (IAA) in the methanol fraction was determined by employing Salper reagent (Gordon and Paleg, 1975). To $1.5 \mathrm{ml}$ of distilled water in a test tube $0.5 \mathrm{ml}$ of methanol residue was mixed, four $\mathrm{ml}$ fresh Salper reagent was rapidly added, kept in complete darkness for one hour and read in spectrophotometer at $535 \mathrm{~nm}$. From a standard curve prepared with known concentration of IAA, the quantity of IAA in the filtrate was calculated ( 1 division $=0.307 \mu \mathrm{g}$ of IAA).

\section{Extraction of siderophore from the medium}

The spent culture fluid was separated from the cells by centrifugation at $7000 \mathrm{rpm}$ for $15 \mathrm{~min}$. The supernatant was concentrated to one fifth of the original volume by flash evaporation at $45^{\circ} \mathrm{C}$. Catechol type phenolates were extracted with ethyl acetate from the culture supernatant twice with an equal volume of solvent at $\mathrm{pH}$ 2.0. the ethyl acetate layer was removed and evaporated to dryness and the residues were dissolved in a minimum quantity of dist. water, while hydroxamate types were measured from the untreated culture supernatant (Schwyn and Neilands, 1987).

Hydrogen Cyanide (HCN) production

Production of HCN was determined as per the method of Wei et al., (1996). Bacteria were grown on TSA supplemented with $4.4 \mathrm{~g} / 1$ of glycine. White filter paper strips soaked in picric acid solution $(2.5 \mathrm{~g}$ of $\mathrm{Na}_{2} \mathrm{CO}_{3}$ and 1 litre of water) were placed in the lid of each Petridish, sealed with parafilm and incubated for two to three days at $28 \pm 2^{\circ} \mathrm{C}$. After incubation HCN production was indicated by the presence of a coloured zone around the bacteria.

\subsection{Testing the antagonism of $P$. fluorescens against $C$.} capsici

Dual culture technique

The antagonistic activity of $P$. fluorescens against $C$. capsici was tested by dual culture technique (Dennis and Webster, 1971). P fluorescens was streaked at one side of Petri dishes (one $\mathrm{cm}$ away from the edge) containing PDA. A $9 \mathrm{~mm}$ mycelial disc from seven days old PDA culture of $C$. capsici was placed at the opposite side of Petri dishes perpendicular to the bacterial streak and incubated at $28 \pm 2^{\circ} \mathrm{C}$ for 15 days. As C. capsici was slow growing in nature, inoculation of $P$. fluorescens was done after $72 \mathrm{~h}$ of inoculation of the pathogen. Petri dishes inoculated with fungal discs alone served as control. Three replications were maintained for each isolate. Observation on width of inhibition zone and mycelial growth of test pathogen was recorded and per cent inhibition of pathogen growth was calculated by using the formula proposed by Vincent (1927). $\quad I=C$ - T / C x 100

Where,

I- Per cent inhibition

C-Mycelial growth of pathogen in control

T- Mycelial growth of pathogen in dual plate.

Poisoned food technique

The culture filtrate of the antagonists was separately incorporated into sterilized PDA medium at 5, 10,15 and 20 per cent by adding the calculated quantity of the culture filtrates to the medium by means of a sterile pipette. The PDA medium without the culture filtrate served as control. The amended media were transferred to sterile Petri dishes separately @ $15 \mathrm{ml}$ and allowed to solidify. Each plate was inoculated at the center with a fifteen day old $(9 \mathrm{~mm})$ PDA culture disc of C. capsici and incubated at room temperature $\left(28 \pm 2^{\circ} \mathrm{C}\right)$ for 15 days. Mancozeb $75 \%$ WP $(0.25 \%)$ served as comparison and three replications were maintained for each treatment. The radial growth of the mycelium was measured after fifteen days of incubation. The results were expressed as per cent growth inhibition over control.

\section{RESULTS}

\subsection{Isolation And Identification Of Biofungicides}

A total of 6 isolates of $P$. fluorescens were isolated from rhizosphere soil of chilli in various part of Tamil Nadu. All the collected isolates of $P$. fluorescens were identified and purified using streak method. After 


\section{E-ISSN: 2321-9637 \\ Available online at www.ijrat.org}

purification they were maintained as stock culture in king's B slant at $10^{\circ} \mathrm{C}$.

\section{Morphological characteristics of $P$. fluorescens} isolates

It was evident from the result presented in table 5 that, isolates of $P$. fluorescens produced round and irregular shaped colony. $\mathrm{Pf}_{1}, \mathrm{Pf}_{2}, \mathrm{Pf}_{3}$, and $\mathrm{Pf}_{5}$, produced colonies with round shapes, whereas $\mathrm{Pf}_{4}$, and $\mathrm{Pf}_{6}$, produced colonies with irregular shapes. All the isolates were found to have light greenish pigments $\left(\mathrm{Pf}_{1}, \mathrm{Pf}_{2}, \mathrm{Pf}_{3} \mathrm{Pf}_{4}, \mathrm{Pf}_{5}\right.$ and $\left.\mathrm{Pf}_{6}\right)$. Among the isolates four isolates showed viz., $\mathrm{Pf}_{1}, \mathrm{Pf}_{2}, \mathrm{Pf}_{4}$, $\mathrm{Pf}_{5}$, fluorescence under UV light, whereas others were non fluorescent (Table 2).

\section{Biochemical characterization of $P$. fluorescence} isolates

The results of the biochemical tests performed for the identification of the effective native isolates of $P$. fluorescens showed that all the isolates produced similar results with regard to gram staining (negative), gelatin liquefaction (positive), catalase test (positive), oxidase test (positive), starch hydrolysis (negative), and fluorescent pigmentation (positive). All the isolates showed positive results in IAA production. Among the isolates $\mathrm{Pf}_{1}$ produced more quantity $(4.1 \mu \mathrm{g} / \mathrm{ml})$ of IAA followed by $\mathrm{Pf}_{6}, \mathrm{Pf}_{4}, \mathrm{Pf}_{3}, \mathrm{Pf}_{2}$ and $\mathrm{Pf}_{5}$ in the decreasing order of merit. The isolate $\mathrm{Pf}_{1}$ recorded maximum $(0.94$ $\mu \mathrm{g} / \mathrm{ml})$ production of siderophores followed by $\mathrm{Pf}_{6}, \mathrm{Pf}_{4}$, $\mathrm{Pf}_{3}, \mathrm{Pf}_{2}$ and $\mathrm{Pf}_{5}$ in the decreasing order of merit. All the isolates showed positive results with regard to hydrogen cyanide production. (Table 3 ).

\subsection{In vitro efficacy of $P$. fluorescens isolates against C. capsici}

Antagonistic activity of $\boldsymbol{P}$. fluorescens isolates against C. capsici (Dual culture Technique)

The result of the dual culture technique indicated that all the isolates inhibited the growth of test fungus significantly (Table 4). Among the isolates, $\mathrm{Pf}_{1}$ produced maximum reduction of mycelial growth $(21.52 \mathrm{~mm})$ accounting for 76.08 per cent reduction over control. This was followed by the isolates $\mathrm{Pf}_{6}, \mathrm{Pf}_{4}, \mathrm{Pf}_{3}, \mathrm{Pf}_{2}$ and $\mathrm{Pf}_{5}$ recording 73.48, 64.04, 67.70, 59.2 and 53.77 Percent respectively. The isolates $\mathrm{Pf}_{5}$ was the least effective recording 53.77 per cent inhibition over control.

Effect of culture filtrates of $\boldsymbol{P}$. fluorescens isolates at different concentration on mycelial growth of $C$. capsici (Poisoned food technique)

The results presented in table 5 revealed that all the isolates showed reduction on mycelial growth of $C$. capsici. Among the isolates, $\mathrm{Pf}_{1}$ at concentration of 5, 10, 15 and 20 per cent concentration showed an increase in the inhibition of the mycelial growth recording 36.07 , $22.87,10.84$ and $2.48 \mathrm{~mm}$ respectively. Also, a general increase in the concentration of the culture filtrate showed an increase in the inhibition of the mycelial growth of the test pathogen. Among the isolates the culture filtrate of $\mathrm{Pf}_{1}$ at 20 per cent conc. was found to be effective in reducing the mycelial growth to the minimum $(2.48 \mathrm{~mm})$ accounting for the highest per cent inhibition $(97.24 \%)$ of the pathogen over control. This was followed by $\mathrm{Pf}_{6} @ 20 \%$ conc recording $(93.08 \%$ inhibition) and $\mathrm{Pf}_{4}(88.11 \%$ inhibition). The least effect was found with isolate $\mathrm{Pf}_{5}$ (69.46 per cent inhibition).

\section{DISCUSSION}

The present study clearly revealed that isolates of $P$. fluorescens produced round and irregular shaped colony. $\mathrm{Pf}_{4}$ and $\mathrm{Pf}_{6}$, produced colonies with irregular shape, $\mathrm{Pf}_{1} \mathrm{Pf}_{2}, \mathrm{Pf}_{3}$, and $\mathrm{Pf}_{5}$, produced colonies with round shape. All the isolates had light greenish pigments. Among the isolates four isolates showed fluroescence under UV light whereas others were non fluorescent. According to Todar (2004), more than half of the Pseudomonas bacteria produced pyocyanin which is a blue-green pigment, while the non-pathogenic saprophyte $P$. fluroescens produced fluorescent pigment that is soluble and greenish. In the present study, all the four isolates produced light green fluorescence on King's B medium under ultraviolet light. The result of the biochemical tests performed for the identification of the effective native isolates of $P$. fluorescens showed that all the isolates produced similar result with regard to gram staining (negative), gelatin liquefaction (positive) catalase test (positive), oxidase test (positive), starch hydrolysis (negative), and fluorescent pigmentation (positive). All the isolates showed positive result in IAA production and $\mathrm{HCN}$ production. Further, the cultural, morphological and biochemical characters have been used to identify and confirm P. fluroescens. Similarly, in the present study also the cultural, morphological and biochemical characters confirmed the isolates to be $P$. fluorescens as reported by earlier workers (Meera and Balabaskar 2012; Meera et al., 2013).

Also, In the present study, all the six isolates of $P$. fluorescens showed varying degrees of antagonism against $C$. capsici. Among the isolates, $\mathrm{Pf}_{1}$ was the most antagonistic and formed the maximum inhibition zone and maximum per cent reduction on the mycelial growth of C. capsici. The mycoparasitic potential of Pseudomonas spp. is well documented (Whipps, 1997) and this phenomenon has often been used as means for in vitro screening of biocontrol agents (Elad et al., 1980). $P$. fluroescens isolates EBS 20 produced higher levels of extracellular metabolites like siderophore, salicylic acid and HCN when compared with other isolates which was highly effective in inhibiting the growth of Pythium aphanidermatum inciting chilli damping-off. (Muthukumar et al., 2010). Similarly, antifungal compounds such as pseudobactin, HCN, salicylic acid and 2-hydroxy phenazine produced by fluorescent pseudomonas suppressed plant pathogenic fungi (Pandey et al., 2006; Reddy et al., 2008). The antifungal metabolites produced by $P$. fluorescens might be attributed as the reason for the reduction in the growth of the pathogen and $P$. fluorescens were known to produce an array of low-molecular weight metabolites some of which were potential antifungal agents $\left(\mathrm{O}^{\prime}\right.$ Dowling and O' Gara, 1994). Earlier workers reported that $P$. fluorescens effectively reduced mycelial growth of other pathogens (Sundaramoorthy et al., 2013; Chacko and Gokulapalan, 2014). 


\section{E-ISSN: 2321-9637 \\ Available online at www.ijrat.org}

\section{REFERENCES}

[1] Anand, T., Chandtasekaran, S., Senthilraja, S.K. and Samiyappan, R. (2010). Integrated control of fruit rot and powdery mildew of chilli using the biological agent Pseuodomonas fluorescens and chemical fungicide. Biocontrol 52: 1-7.

[2] Masoodi, L., Anwar, A., Ahmed, S. and Sofi, A.T. (2012). Cultural, morphological and pathogenic variability Colletotrichum capsici causing dieback and fruit rot of chilli. Asian J. Plant Pathol. pp:1-13

[3] Kraikruan, N.W., Sangchote, S. and Sukprakarn, S. (2008). Effect of capsaicin on germination of Colletotrichum capsici conidia. Kasetssart J. (Nat. Sci.) 42: 417-422.

[4] Hemmannuvar, V., Asalmol, M.N., Kale, V.P. and Ingle, S.T. (2001). Seed borne and airborne fungi of chilli, incidence and effect on seed germination. Seed res. 29: 76-79.

[5] Shovan, L.R., Bhuiyan, A.K.M., Begum, A.J. and Pervez, Z. (2008). In vitro control of Colletotrichum dematium causing anthracnose of soybean by fungicides, plant extracts and Trichoderma harzianum. Int. J. Sustain Crop Production 3: 10-17.

[6] Bajpai, V.K. and Kang, S.C. (2010). Antifungal activity of leaf essential oil and extracts of metasequia glyptostroboides miki ex hu. J. Am. Oil Chem. Soc., 87: 327- 336.

[7] Allu, S., Kumar, N.P. and Audipudi, V.A. (2014). Isolation, Biochemical and PGP characterization of endophytic Pseudomonas aeruginosa isolated from chilli red fruit antagonistic against chilli anthracnose disease. Int. J. Curr. Microbiol. Appl. Sci. 3(2): 318329.

[8] Sundaramoorthy, S. and Balabaskar, P. (2012). Consortial effect of endophytic and plant growth promoting rhizobacteria for the management of early blight of tomato incited by Alternaria solani. J. Plant Pathol. Microbiol. 3:7.

[9] Chen, C., Belanger, R.R., Benhamou, N. and Paullitz, T.C. (2000). Defense enzymes induced in cucumber roots by treatment with plant-growth promoting rhizobacteria (PGPR). Physiol. Mol. Plant Pathol. 56:13-23.

[10] M'Piga, P., Belanger, R.R., Paulitz, T.C. and Benhamou, N. (1997). Increased resistance to Fusarium oxysporum f. sp. lycopersici in tomato plants treated with the endophytic bacterium Pseudomonas fluorescens strain 63-28. Physiol. Mol. Plant Pathol. 50: 301-320.

[11] Nagarajkumar, M., Bhaskaran, R. and Velazhahan, R. (2004). Involvement of secondary metabolites and extracellular lytic enzymes produced by Pseusomonas fluoresces in inhibition of Rhizoctonia solani, the rice sheath blight pathogen. Microbiol. Res. 159(1): 73-81.

[12] Breed, R.S., Murray, E.G. and Smith, N.R. (1989). Bergeys' Manual of Determinative Bacteriology, $9^{\text {th }}$ ed., William and Wilkins Co., Baltimore, Maryland, 1094.
[13] Cyrabree, T. and Hindshill, G. (1975). Fundamental experiments in Microbiology, W.B.Saunders Company, London, pp: 61-66.

[14] Stolpe, S. and Godkeri, K. (1981). Non pathogenic members of Pseudomonas. In: Marthiner (ed.) The Prokaryotes, Springer-Verlag, New York. pp.719-741.

[15] King, E.O., Ward, M.K. and Raney, D.E. (1954). Two simple media for the demonstration of pyocyanin and fluorescein. J. Lab. Clin. Med. 44: 301-307.

[16] Gordon, S.A. and Paleg, L.G. (1957). Quantitaive measurement of Indole acetic acid. Physiol. Plant 10: 37- 48.

[17] Schwyn, B. and Neilands, J.B. (1987). Universal chemical assay for the detection and determination of siderophores. Ann. Biochem, 160: 47-56.

[18] Wei, G., Kloepper, J.W. and Tuzun, S. (1996). Induced systemic resistance to cucumber diseases and increased plant growth by plant growth promoting rhizobacteria under field conditions. Phyto pathol. 86: 221-224.

[19] Dennis, L. and Webstar, J. (1971). Antagonistic properties of species-groups of Trichoderma. The production of non-volatile antibiotics. Trans. Bri. Mycol. Soc. 57: 25-39.

[20] Vincent, J.M. (1927). Distortion of fungal hyphae in the presence of certain inhibitors. Nature 59: 850.

[21] Todar, K. (2004). Psudomonads and related bacteria. Todars online text of bacteriology.http://textbookofbacteriology.net/pse udomonas.etc.

[22] Meera, T. and Balabaskar, P. (2012). Isolation and characterization of Pseudomonas fluorescens from rice fields. Int. J. Food Agric. Vet. 2(1): 113120.

[23] Meera, T., Balabaskar, P. and Vengadesh kumar, L. (2013). Potential of Pseudomonas fluorescens and Eucalyptus globules extract on inducing defense molecules against rice sheath rot disease. Ann. Plant Prot. Sci. 21 (2): 315-321.

[24] Whipps, J.M. (1997). Developments in the biological control of soil-borne plant pathogens. Adv. Bot. Res. 26:1-134.

[25] Elad, Y., Chet, I. and Katan, J. (1980). Trichoderma harzianum: A biocontrol agent effective against Sclerotium rolfsii and Rhizoctonia solani. Phytopathol. 70: 119-121.

[26] Muthukumar, A., Nakkeeran, S., Eswaran, A and Sangeetha, G. (2010). In vitro efficacy of bacterial endophytes against the chilli damping off pathogen Pythium aphanidermatum. Phytopathol. Mediterr. 49: 179-186.

[27] Pandey, A., Trivedi Kumar, K. and Palni, L.S. (2006). Characterization of phosphate solubilizing and antagonistic strain of Pseudomonas putida (BO) isolated from a Sub-Alpine location in the Indian central Himalaya. Curr. Microbiol. 53: 102-107. 
[28] Reddy, B.P., Reddy, K.R.N., Subba Rao, B.P. and Rao, K.S. (2008). Efficacy of antimicrobial metabolites of Pseudomonas fluorescens against rice fungal pathogens. Curr. Trend Biotechnol. Pharm. 2: 178-182.

[29] O'Dowling, D.N. and O'Gara, F. (1994). Metabolites of Pseudomonas involved in the biocontrol of plant disease. Trends Biotechnol. 12: $133-141$.

[30] Sundaramoorthy, S., Karthiba, L., Reguchander, T. and Samiyappan, R. (2013). Ecofriendly approaches of potential microbial bioagents in management of sheath rot disease in rice caused by S. oryzae. Plant Pathol. J. 12 (2): 98-103.

[31] Chacko, T.S. and Gokulapalan, C. (2014). In vitro study of fungicides and biocontrol agents against Colletotrichum capsici causing anthracnose of chilli (Capsicum annuumm L.). Int. J. Appl. Pure Sci and Agric. 1(05): 93- 98.

Table 2. Morphological characteristics of $P$. fluorescens isolates

\begin{tabular}{|c|c|c|c|c|}
\hline Isolates & Cell shape & Colony type & Colony colour/ pigmentation & Reaction to UV light \\
\hline $\mathrm{Pf}_{1}$ & Rod & Round & Light greenish & Fluorescent \\
\hline $\mathrm{Pf}_{2}$ & Rod & Round & Light greenish & Fluorescent \\
\hline $\mathrm{Pf}_{3}$ & Rod & Round & Light greenish & Fluorescent \\
\hline $\mathrm{Pf}_{4}$ & Rod & Irregular & Light greenish & Fluorescent \\
\hline $\mathrm{Pf}_{5}$ & Rod & Round & Light greenish & No reaction \\
\hline $\mathrm{Pf}_{6}$ & Rod & Irregular & Light greenish & \\
\hline
\end{tabular}

Table 3. Bio chemical characterization of $P$. fluorescence isolates

\begin{tabular}{|c|c|c|c|c|c|c|c|c|c|}
\hline \multirow[b]{2}{*}{$\begin{array}{c}\text { Isolate } \\
\mathrm{s}\end{array}$} & \multicolumn{9}{|c|}{ Parameters } \\
\hline & $\begin{array}{c}\text { Gram } \\
\text { staining }\end{array}$ & $\begin{array}{c}\text { Gelatin } \\
\text { liquefactio } \\
\mathbf{n}\end{array}$ & $\begin{array}{c}\text { Catalas } \\
\text { e test }\end{array}$ & $\begin{array}{l}\text { Oxidas } \\
\text { e test }\end{array}$ & $\begin{array}{c}\text { Starch } \\
\text { hydrolysi } \\
\text { S }\end{array}$ & $\begin{array}{c}\text { Fluorescenc } \\
\text { e pigment }\end{array}$ & $\begin{array}{c}* \text { Estimatio } \\
\text { n of IAA } \\
(u g / m l)\end{array}$ & $\begin{array}{c}\text { *Siderophore } \\
\text { production } \\
\text { (Hydroxamate } \\
\text { ) } \\
(\underline{\mathrm{ug} / \mathrm{ml})}\end{array}$ & $\begin{array}{c}\text { *Hydroge } \\
\text { n cyanide } \\
\text { productio } \\
\text { n } \\
(\mathbf{u g} / \mathrm{ml})\end{array}$ \\
\hline $\mathrm{Pf}_{1}$ & $\begin{array}{c}\text { Negativ } \\
\mathrm{e}\end{array}$ & Positive & Positive & Positive & Negative & Positive & $4.1^{\mathrm{a}}$ & $0.94^{\mathrm{a}}$ & $8.82^{\mathrm{a}}$ \\
\hline $\mathrm{Pf}_{2}$ & $\begin{array}{c}\text { Negativ } \\
\mathrm{e}\end{array}$ & Positive & Positive & Positive & Negative & Positive & $2.6^{\mathrm{e}}$ & $0.65^{\mathrm{e}}$ & $6.88^{\mathrm{f}}$ \\
\hline $\mathrm{Pf}_{3}$ & $\begin{array}{c}\text { Negativ } \\
\mathrm{e}\end{array}$ & Positive & Positive & Positive & Negative & Positive & $3.1^{\mathrm{d}}$ & $0.88^{\mathrm{c}}$ & $8.28^{\mathrm{d}}$ \\
\hline $\mathrm{Pf}_{4}$ & $\begin{array}{c}\text { Negativ } \\
\mathrm{e}\end{array}$ & Positive & Positive & Positive & Negative & Positive & $3.6^{\mathrm{c}}$ & $0.86^{\mathrm{d}}$ & $8.41^{\mathrm{c}}$ \\
\hline $\mathrm{Pf}_{5}$ & $\begin{array}{c}\text { Negativ } \\
\mathrm{e}\end{array}$ & Positive & Positive & Positive & Negative & Positive & $2.5^{\mathrm{f}}$ & $0.62^{\mathrm{f}}$ & $6.97^{\mathrm{e}}$ \\
\hline $\mathrm{Pf}_{6}$ & $\begin{array}{c}\text { Negativ } \\
\mathrm{e}\end{array}$ & Positive & Positive & Positive & Negative & Positive & $3.8^{\mathrm{b}}$ & $0.90^{\mathrm{b}}$ & $8.54^{\mathrm{b}}$ \\
\hline
\end{tabular}

*Values in the column followed by same letters not differ significantly by DMRT $(\mathrm{P}=0.05)$

Table 4. Antagonistic activity of $P$. fluorescens isolates against $C$. capsici

(Dual culture technique)

\begin{tabular}{|c|c|c|c|}
\hline S. No. & Native isolates & $\begin{array}{c}* \text { Mycelial growth the pathogen } \\
(\mathbf{m m})\end{array}$ & Per cent inhibition over control (\%) \\
\hline 1. & $\mathrm{Pf}_{1}$ & $21.52^{\mathrm{a}}$ & 76.08 \\
\hline 2. & $\mathrm{Pf}_{2}$ & $36.71^{\mathrm{e}}$ & 59.21 \\
\hline 3. & $\mathrm{Pf}_{3}$ & $29.07^{\mathrm{d}}$ & 67.70 \\
\hline 4. & $\mathrm{Pf}_{4}$ & $32.36^{\mathrm{c}}$ & 53.04 \\
\hline 5. & $\mathrm{Pf}_{5}$ & $41.60^{\mathrm{f}}$ & 73.48 \\
\hline 6. & $\mathrm{Pf}_{6}$ & $23.86^{\mathrm{b}}$ & 00.00 \\
\hline 7. & Control & $90.00^{\mathrm{g}}$ & \\
\hline
\end{tabular}


International Journal of Research in Advent Technology, Vol.7, No.4, April 2019

$$
\text { E-ISSN: 2321-9637 }
$$

Available online at www.ijrat.org

Values in the column followed by common letters do not differ significantly by DMRT $(\mathrm{P}=0.05)$

Table 5. Effect of culture filtrates of $P$. fluorescens isolates at different concentrations on mycelial growth of $C$. capsici

(Poisoned food technique)

\begin{tabular}{|c|c|c|c|c|c|c|c|c|c|}
\hline \multirow[b]{2}{*}{ S. No. } & \multirow{2}{*}{ Isolates } & \multicolumn{4}{|c|}{ *Mycelial growth the pathogen $(\mathrm{mm})$} & \multicolumn{4}{|c|}{ Per cent inhibition over control } \\
\hline & & $5 \%$ & $10 \%$ & $15 \%$ & $20 \%$ & $5 \%$ & $10 \%$ & $15 \%$ & $20 \%$ \\
\hline 1. & $\mathrm{Pf}_{1}$ & $36.07^{\mathrm{a}}$ & $22.87^{\mathrm{a}}$ & $10.84^{\mathrm{a}}$ & $2.48^{\mathrm{a}}$ & 59.92 & 74.58 & 87.95 & 97.24 \\
\hline 2. & $\mathrm{Pf}_{2}$ & $56.79^{\mathrm{e}}$ & $44.74^{\mathrm{e}}$ & $31.30^{\mathrm{e}}$ & $22.33^{\mathrm{e}}$ & 36.90 & 50.28 & 65.22 & 75.18 \\
\hline 3. & $\mathrm{Pf}_{3}$ & $51.82^{\mathrm{d}}$ & $39.18^{\mathrm{d}}$ & $26.45^{\mathrm{d}}$ & $15.99^{\mathrm{d}}$ & 42.42 & 56.46 & 70.61 & 82.23 \\
\hline 4. & $\mathrm{Pf}_{4}$ & $46.61^{\mathrm{c}}$ & $33.11^{\mathrm{c}}$ & $20.82^{c}$ & $10.70^{\mathrm{c}}$ & 48.21 & 63.21 & 76.86 & 88.11 \\
\hline 5. & $\mathrm{Pf}_{5}$ & $61.77^{f}$ & $50.76^{\mathrm{f}}$ & $36.17^{f}$ & $27.48^{f}$ & 31.36 & 43.60 & 59.81 & 69.46 \\
\hline 6. & $\mathrm{Pf}_{6}$ & $41.29^{b}$ & $27.81^{b}$ & $15.78^{b}$ & $6.22^{b}$ & 54.12 & 69.00 & 82.46 & 93.08 \\
\hline 7. & $\begin{array}{c}\text { Mancozeb } 75 \% \\
\text { WP }(0.25 \% \text { conc. })\end{array}$ & $0.00^{\mathrm{a}}$ & $0.00^{\mathrm{a}}$ & $0.00^{\mathrm{a}}$ & $0.00^{\mathrm{a}}$ & 100 & 100 & 100 & 100 \\
\hline 8. & Control & $90.00^{\mathrm{g}}$ & $90.00^{\mathrm{g}}$ & $90.00^{\mathrm{g}}$ & $90.00^{\mathrm{g}}$ & 0.00 & 0.00 & 0.00 & 0.00 \\
\hline
\end{tabular}

*Values in the column followed by same letters not differ significantly by DMRT $(\mathrm{P}=0.05)$ 